N.V. Roik, L.A. Belyakova, M.O. Dziazko, O.I. Oranska

\title{
DECORATION OF MCM-41 PORE ENTRANCES WITH AMINO-CONTAINING GROUPS FOR PH-CONTROLLED RELEASE OF para-AMINOBENZOIC ACID
}

\author{
Chuiko Institute of Surface Chemistry of National Academy of Sciences of Ukraine \\ 17 General Naumov Str., Kyiv, 03164, Ukraine, E-mail: roik_nadya@ukr.net
}

Selectively modified silica materials with uniform hexagonally ordered cylindrical mesopores were synthesized by combination of sol-gel condensation and postsynthetic chemical modification. Hexagonally arranged porous structure of silica carriers was confirmed by X-ray diffraction and low-temperature ad-desorption of nitrogen. Content of functional groups immobilized onto external surface of silica particles was determined from chemical analysis of surface reaction products. Release capability of MCM-41 mesoporous silicas selectively modified with $N$-(2-aminoethyl)-3-aminopropyl or $N$-[N'-( $N$ '-phenyl)-2aminophenyl]-3-aminopropyl groups was studied by use of para-aminobenzoic acid as model biologically active substance. It has been found that desorption of aromatic amino acid from mesoporous channels of silica can be regulated using $\mathrm{pH}$-sensitive functional groups which are chemically bounded with outer silica surface.

Keywords: sol-gel synthesis, vapour-phase modification, desorption, surface properties

\section{INTRODUCTION}

The potential importance of MCM-41 silica materials as drug carriers is caused by their chemical stability, biocompatibility, high surface area, large pore volume, uniform and tunable pores of molecular size, and controllable participation in chemical reactions with a wide range of modifiers $[1,2]$. The geometrical complementarity of MCM-41 pores and adsorbate molecules along with chemical affinity between guest molecules and functional groups lining mesopore walls belong to the main factors influencing drug molecules adsorption-desorption processes. It has been demonstrated that geometrical parameters of pores can be affected by templating agents selection [3-8] or postsynthetic activation [9, 10], whereas chemical features of surface layer can be sufficiently changed by various reactions of weakly acidic silanol groups with appropriate modifiers [11-16].

Delivery of many biologically active substances requires «zero release» before reaching targeted cells or tissues. However, desorption of guest molecules is usually observed even at the first contact of functionalized carrier with aqueous solution. In order to avoid this difficulty, construction of molecular or supramolecular devices preventing uncontrollable release of biologically active molecules can be realized [17-30]. Protolytically ionizable self-assembling organic moieties chemically immobilized near pore orifices of MCM-41 silica can serve as surface pH-responsive gatekeepers. As strength of interaction between ionizable organic groups located near by pore orifices is directly dependent on their protolytic properties, the release of entrapped molecules from mesoporous channels of silica carrier can be influenced by $\mathrm{pH}$ change.

Herein, we propose an approach for selective modification of external surface of MCM-41 particles with $\mathrm{pH}$-responsive nanovalves constructed from ionizable N-(2-aminoethyl)3-aminopropyl and N-[N'-(N'-phenyl)-2aminophenyl]-3-aminopropyl groups. These protolytic species immobilized near by pore orifices can associate in neutral form and prevent release of para-aminobenzoic acid ( $p$-ABA) from the mesoporous bulk. Liberation of aromatic amino acid proceeds at protonation of blocking groups in acidic medium. Repulsion of positively charged amino groups provides the opening of pore entrances and unhindered extrication of $p$-ABA.

\section{EXPERIMENTAL}

Tetraethylorthosilicate (from Merck, purity $\geq 99 \%$ ), (3-chloropropyl)triethoxysilane (from Aldrich, purity $\geq 95 \%$ ), cetyltrimethyl- 
ammonium bromide (from Merck, purity $\geq 97 \%$ ), 2-aminodiphenylamine (from Merck, purity $\geq 97 \%$ ), 1,2-ethylenediamine (from Merck, purity $\geq 99 \%$ ), para-aminobenzoic acid (from AppliChem, purity $\geq 98.5 \%$ ), standard volumetric solutions of phosphate buffer and hydrochloric acid (all from RIAP, analytical grade), aqueous ammonia $25 \%$ (from Reakhim, analytical grade), acetonitrile (from Reakhim, analytical grade), hydrochloric acid $37 \%$ (from Reakhim, chemical grade), and ethanol $96 \%$ (from Reakhim, chemical grade) were used without additional purification.

Methods and instruments. X-ray diffraction spectra were registered by use of a Diffractometer DRON-4-02 with monochromatic $\mathrm{Cu} K_{\alpha}$ emission $(\lambda=1.54178 \AA)$ and nickel filter. Interplanar distance (d) was estimated using the Bragg diffraction equation [31]. The unit cell parameter (a) was calculated by equation represented in [32]. The diameter of hexagonally arranged cylindrical pores (D) was evaluated from the repeating distance between reflecting planes (d) and pore volume $\left(V_{p}\right)$ calculated from low-temperature ad-desorption isotherms of nitrogen [33]:

$\mathrm{D}=\mathrm{cd} \sqrt{\frac{\rho \mathrm{V}_{\mathrm{p}}}{1+\rho \mathrm{V}_{\mathrm{p}}}}$,

where $\mathrm{c}$ is the constant dependent on the pore shape, it can be expressed as $\mathrm{c}=\sqrt{\frac{8}{\sqrt{3} \cdot \pi}}$ when pores are modeled as hexagonal prisms; $\rho$ is the density of the pore walls that can be equal to that of amorphous silica $\left(2.2 \mathrm{~g} / \mathrm{cm}^{3}\right.$ [33]); $\mathrm{V}_{\mathrm{p}}$ is the pore volume obtained from the nitrogen adsorption isotherm by the t-plot method.

The pore wall thickness (B) was calculated by the Eq. 2 as the difference between the values of unit cell parameter (a) assessed from the X-ray diffraction studies and pore diameter (D) calculated from the low-temperature ad-desorption of nitrogen:

$\mathrm{B}=\mathrm{a}-\mathrm{D}$.

Characterization of pore structure of silica materials was performed using the data of low-temperature ad-desorption of nitrogen obtained in the region of relative pressures from 0.06 to 0.99 in increment of 0.015 with a Sorptometer Kelvin-1042. Specific surface area
$\left(\mathrm{S}_{\mathrm{BET}}\right)$ was calculated by the BET equation. The pore diameters (D) and their distributions (dV/dD) were calculated by density functional theory (DFT) method. Pore volumes were estimated at relative pressure of 0.99 .

UV spectra of $p$-ABA buffer solutions were recorded in the $200-400 \mathrm{~nm}$ spectral range with a Specord M-40. Quarts cells with 2 and $10 \mathrm{~mm}$ path length were used. All spectroscopic measurements were made with temperature-controlled cell holder and water bath.

$\mathrm{pH}$ values of $p$-ABA buffer solutions were measured by an Ionometer I-120.1.

Concentrations of grafted 3-chloropropyl groups of mesoporous silicas were determined by titration of chloride-anions released as a result of alkaline hydrolysis of the $\mathrm{C}-\mathrm{Cl}$ bonds [34] with mercury(II) nitrate [35].

The content of $\mathrm{N}$-(2-aminoethyl)-3-aminopropyl and $\mathrm{N}$-[N'-(N'-phenyl)-2aminophenyl]-3-aminopropyl groups of modified silica was calculated from the results of potentiometric titration with $0.01 \mathrm{M} \mathrm{HCl} \mathrm{[36].}$

Synthesis of mesoporous silicas. Mesoporous silicas MCM-41 and Cl-MCM-41 were prepared in water-ethanol-ammonia solution according to reported co-condensation procedure [37] with cetyltrimethylammonium bromide as a structure directing agent, with tetraethylorthosilicate and (3-chloropropyl)triethoxysilane as a silica source.

Selective chemical modification of outer surface of template-containing MCM-41 silica particles with vapours of (3-chloropropyl)triethoxysilane was carried out by use of special vacuum equipment [37]. Mesoporous silica was placed into a quarts evacuated reactor and degassed at $393 \mathrm{~K}$ for $2 \mathrm{~h}$ before silane coupling. Then adsorber vessel filled with (3-chloropropyl)triethoxysilane was frozen, degassed in a vacuum for $10 \mathrm{~min}$, unfrozen, and connected with a reactor in which there was mesoporous silica. The vacuum-pretreated system containing mesoporous silica and modifier was heated up to $383 \mathrm{~K}$ for $2 \mathrm{~h}$. The reactor was evacuated to remove volatile reaction products and unreacted modifier. After the chemical modification procedure the surfactant was extracted from the pore channels of $\mathrm{Cl}_{\mathrm{VP}}-\mathrm{MCM}-41$ silica into acid-ethanol medium.

Directed immobilization of $\mathrm{N}$-(2-aminoethyl)-3-aminopropyl groups on external surface of template-containing Cl-MCM-41 silica was realized in vapour phase by 
use of 1,2-ethylenediamine as modifier in accordance with the synthetic procedure described for $\mathrm{Cl}_{\mathrm{VP}}-\mathrm{MCM}-41$. Reaction of nucleophilic substitution between surface chloropropyl groups of Cl-MCM-41 silica and vapours of 1,2-ethylenediamine is represented in Scheme 1.
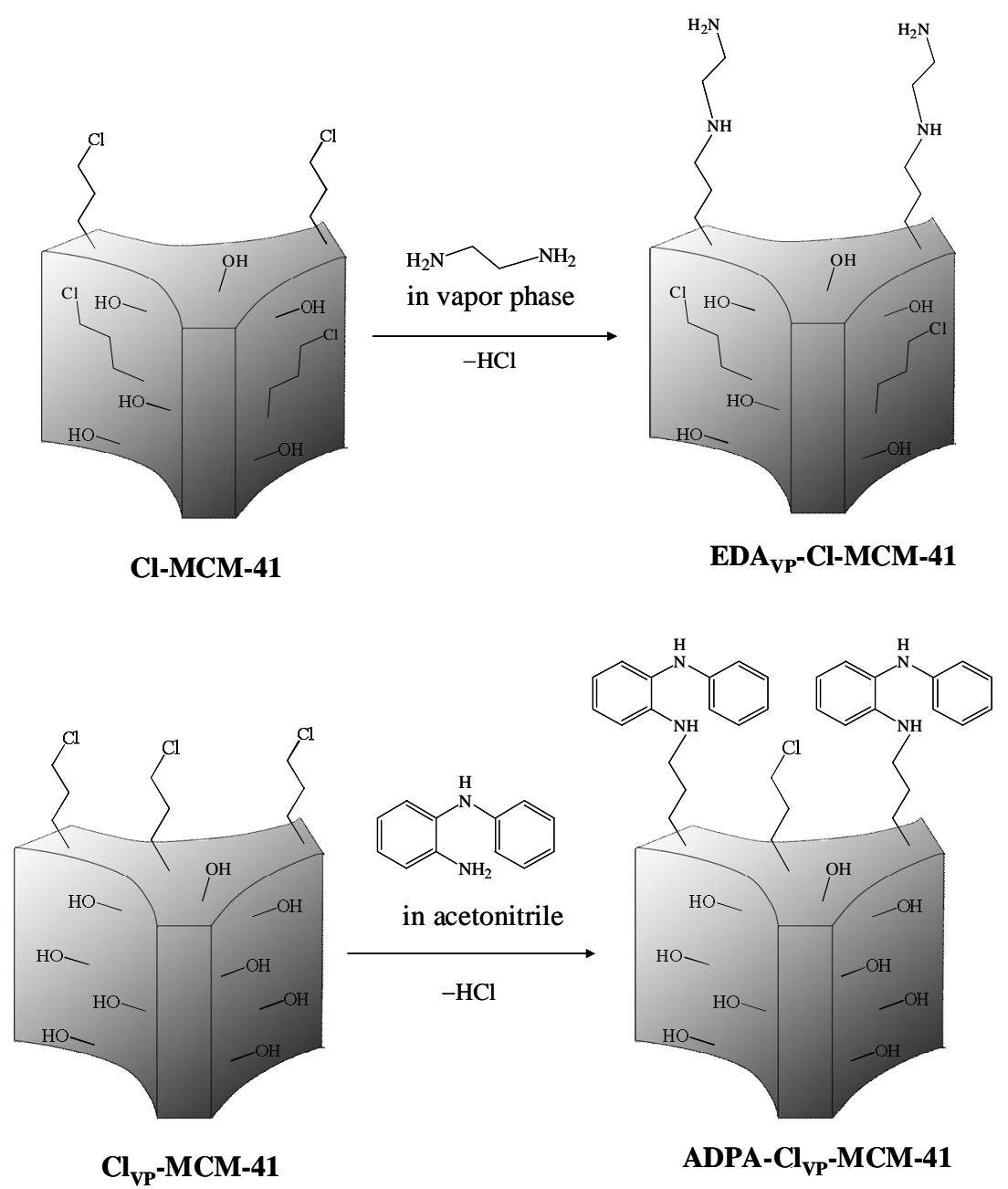

Scheme 1. Chemical immobilization of N-(2-aminoethyl)-3-aminopropyl and N-[N'-(N'-phenyl)-2aminophenyl]-3-aminopropyl groups on outer surface of Cl-MCM-41 and $\mathrm{Cl}_{\mathrm{VP}}-\mathrm{MCM}-41$, respectively

ADPA-Cl $\mathrm{VP}_{\mathrm{VP}}-\mathrm{MCM}-41$ silica was prepared by reaction between primary amino groups of 2-aminodiphenylamine (2-ADPA) and 3-chloropropyl groups of $\mathrm{Cl}_{\mathrm{VP}}-\mathrm{MCM}-41$ silica (Scheme 1). Briefly, $\mathrm{Cl}_{\mathrm{VP}}-\mathrm{MCM}-41$ silica (2 g) was placed into a three-necked reactor supplied with a stirrer and a reflux condenser, and suspended in a small amount of acetonitrile $(20 \mathrm{ml})$ at room temperature for $30 \mathrm{~min}$. Then, 2-ADPA (0.368 g) was dissolved in acetonitrile $(5 \mathrm{ml})$ and added to reaction mixture. Modification was carried out with continuous stirring at solvent reflux temperature $\left(355 \mathrm{~K}\right.$ ) for $12 \mathrm{~h}$. Synthesized ADPA-Cl $\mathrm{VP}_{\mathrm{V}}-\mathrm{MCM}-41$ silica was filtered and washed sequentially with acetonitrile, ethanol, and distilled water. Resulting product was dried in air at $373 \mathrm{~K}$ for $2 \mathrm{~h}$, then cooled to room temperature and kept in desiccator before use.

Loading of mesoporous silicas with $p$-ABA. Powdered MCM-41-type materials were loaded with $p$-ABA by soaking them in a concentrated solution of biologically active compound. Batch of mesoporous silica $(0.5 \mathrm{~g})$ was added to solution of para-aminobenzoic acid $(1 \mathrm{~g}$ in $10 \mathrm{ml}$ of absolute ethanol). Mixture was kept under continuous magnetic stirring at $293 \mathrm{~K}$ for $72 \mathrm{~h}$. Then, suspension was filtered in vacuum, solid product was washed with small amount of ethanol to remove adsorbate from external surface of carrier, and dried at room temperature. To take away trace amounts of ethanol, $p$-ABA-loaded mesoporous silica was dried in vacuum for $2 \mathrm{~h}$ and stored in 
desiccator. Content of absorbed $p$-ABA was estimated by thermal analysis of resulting acid-loaded silica material.

Release of $p-A B A$ from mesoporous silicas. $p$-ABA release procedure was performed in phosphate buffer and hydrochloric acid solutions with $\mathrm{pH}=6.86$ and $\mathrm{pH}=1.00$, respectively, at $293 \mathrm{~K}$ over $72 \mathrm{~h}$. For this, batches of mesoporous silica impregnated with $p$-ABA $(0.01 \mathrm{~g})$ were placed into $100 \mathrm{ml}$ volumetric flasks, and phosphate buffer solution $(20 \mathrm{ml})$ was added under continuous stirring. Aliquots of extracted solutions were removed for analysis at time intervals from $5 \mathrm{~min}$ to $72 \mathrm{~h}$. Concentration of $p$-ABA in release medium was determined with UV spectroscopy by monitoring the changes in absorbance at $266 \mathrm{~nm}$ in phosphate buffer solutions and at $271 \mathrm{~nm}$ in hydrochloric acid solutions. Calibration curves of $p$-ABA in phosphate buffer and hydrochloric acid solutions were plotted in the range $0.05-1 \mathrm{mmol} \cdot \mathrm{g}^{-1}$. Content of $p$-ABA filling the pore volume of mesoporous carrier was calculated from desorption data.

\section{RESULTS AND DISCUSSION}

Controlled release of biologically active substance is an effective approach to attain its high local concentration in diseased tissues. Therefore, anchoring of functional groups disposed to association on external surface of silica particles is used for development of nanovalves for delivery application. In the present paper, results of X-ray diffraction and low-temperature ad-desorption of nitrogen were used to confirm hexagonal order of porous structure of sol-gel synthesized silica materials and silicas selectively modified with $\mathrm{N}$-(2-aminoethyl)-3-aminopropyl or $\mathrm{N}$-[N'-(N'phenyl)-2-aminophenyl]-3-aminopropyl groups by postsynthetic activation.

Powder X-ray diffraction patterns of MCM-41, Cl-MCM-41, Cl $_{\mathrm{VP}}-\mathrm{MCM}-41, \mathrm{EDA}_{\mathrm{VP}}-\mathrm{Cl}-\mathrm{MCM}-41$, and $\mathrm{ADPA}-\mathrm{Cl}_{\mathrm{VP}}-\mathrm{MCM}-41$ silicas are shown in Fig. 1. Three well-resolved diffraction peaks assigned to (100), (110) and (200) reflections are registered in all diffractograms confirming formation of two-dimensional periodic hexagonal lattice which is typical for MCM-41 materials.

Postsynthetic modification of MCM-41 with (3-chloropropyl)triethoxysilane in vapour phase leads to increase in intensity of (100) reflection on diffractogram of $\mathrm{Cl}_{\mathrm{vP}}-\mathrm{MCM}-41$ (Fig. 1). Moreover, position of diffraction peak which corresponds to (100) reflection of hexagonally ordered structure in diffractogram of $\mathrm{Cl}_{\mathrm{VP}} \mathrm{MCM}-41$ is in a good agreement with its location for parent MCM-41 silica (Fig. 1, curves 1,3). So, vapour-phase treatment of template-containing MCM-41 with (3-chloropropyl)triethoxysilane has no effect on the mesoporous structure of silica carrier and results in selective chemical modification of outer surface of silica particles.

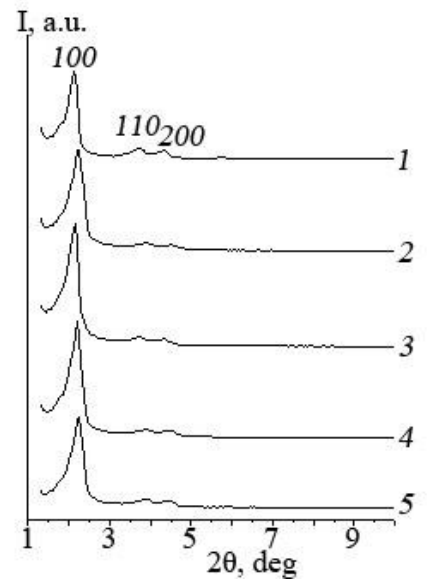

Fig. 1. X-ray diffraction patterns of MCM-41 (1), Cl-MCM-41 (2), $\mathrm{Cl}_{\mathrm{YP}}-\mathrm{MCM}-41$ (3), EDA ${ }_{\mathrm{VP}}$ Cl-MCM-41 (4), and ADPA-Cl $\mathrm{VP}_{\mathrm{VP}} \mathrm{MCM}-41$ (5)

Preservation of well ordered hexagonal structure is observed after postsynthetic functionalization of Cl-MCM-41 silica with 1,2-ethylenediamine in vapour phase. Intensity of (100), (110), and (200) reflections on diffractogram of $\mathrm{EDA}_{\mathrm{vp}}-\mathrm{Cl}-\mathrm{MCM}-41$ is higher than that of Cl-MCM-41 (Fig. 1, curves 2, 4). It should be noted that position of (100) peak for Cl-MCM-41 and $\mathrm{EDA}_{\mathrm{VP}} \mathrm{Cl}-\mathrm{MCM}-41$ after template extraction almost coincides. Hence, functionalization occurs mainly on exterior surface of mesoporous silica.

Immobilization of N-[N'-(N'-phenyl)-2aminophenyl]-3-aminopropyl groups in surface layer of $\mathrm{Cl}_{\mathrm{VP}}-\mathrm{MCM}-41$ does not cause noticeable changes in low-angle peak position (Fig. 1, curves 3,5 ). Thus, structural parameters of selectively modified chloropropylsilica are kept after postsynthetic activation with 2-ADPA (Table 1).

Specific surface areas of silica carriers were calculated by the BET equation, pore diameters and their distributions were estimated from isotherms of nitrogen low-temperature ad-desorption using DFT method (Fig. 2, Table 1). Postsynthetic vapour-phase functionalization of outer surface of MCM-41 and Cl-MCM-41 with 3-chloropropyl and N-(2-aminoethyl)-3-aminopropyl 
groups, respectively, is accompanied by insignificant change of specific surface area of resulting $\mathrm{Cl}_{\mathrm{VP}}-\mathrm{MCM}-41$ and $\mathrm{EDA}_{\mathrm{VP}}-\mathrm{Cl}-\mathrm{MCM}-41$ silicas. At the same time, it proceeds without reducing the pore size and pore volume of silica materials (Table 1). Obviously, the technique of (3-chloropropyl)triethoxysilane and 1,2-ethylene- diamine immobilization on exterior surface of template-containing $\mathrm{Cl}-\mathrm{MCM}-41$ particles prevents the formation of organic layer in their pores. As a result, mesoporous structure of initial MCM-41 and Cl-MCM-41 silicas with cylindrical pores of uniform size is retained after postsynthetic modification.

Table 1. Structural parameters of ordered mesoporous silicas

\begin{tabular}{|c|c|c|c|c|c|c|c|}
\hline \multirow[t]{2}{*}{ Silica } & \multicolumn{4}{|c|}{ X-ray analysis } & \multicolumn{3}{|c|}{ Low-temperature ad-desorption of nitrogen } \\
\hline & $\mathrm{d}_{100}, \mathrm{~nm}$ & a, $\mathbf{n m}$ & D, nm & $\mathbf{B}, \mathbf{n m}$ & $\mathrm{S}, \mathrm{m}^{2} / \mathrm{g}$ & $\mathrm{V}, \mathrm{cm}^{3} / \mathrm{g}$ & $\mathrm{D}, \mathrm{nm}$ \\
\hline MCM-41 & 4.17 & 4.82 & 3.67 & 1.15 & 873 & 0.67 & 3.54 \\
\hline Cl-MCM-41 & 3.98 & 4.59 & 3.73 & 0.86 & 763 & 0.81 & 3.54 \\
\hline $\mathrm{Cl}_{\mathrm{VP}}-\mathrm{MCM}-41$ & 4.13 & 4.77 & 3.70 & 1.07 & 655 & 0.71 & 3.76 \\
\hline $\mathrm{EDA}_{\mathrm{VP}}-\mathrm{Cl}-\mathrm{MCM}-41$ & 4.02 & 4.64 & 3.87 & 0.77 & 808 & 0.88 & 3.54 \\
\hline $\mathrm{ADPA}-\mathrm{Cl}_{\mathrm{VP}}-\mathrm{MCM}-41$ & 4.10 & 4.73 & 3.68 & 1.05 & 610 & 0.71 & 3.76 \\
\hline
\end{tabular}

$\mathrm{d}_{100}$ - distance between the reflecting planes; $\mathrm{a}$ - distance between the pore centers of the hexagonal structure;

$\mathrm{D}$ - pore diameter; $\mathrm{B}$ - pore wall thickness; $\mathrm{S}$ - specific surface area; $\mathrm{V}$ - total pore volume

It can be seen (Table 1) that specific surface area of $\mathrm{Cl}_{\mathrm{VP}}-\mathrm{MCM}-41$ decreases from 655 to $610 \mathrm{~m}^{2} \cdot \mathrm{g}^{-1}$ as a result of $\mathrm{N}-\left[\mathrm{N}^{\prime}-\left(\mathrm{N}^{\prime}-\right.\right.$ phenyl)-2aminophenyl]-3-aminopropyl groups immobilization. At the same time, shrinkage of pore volume is not observed after postsynthetic chemical functionalization of $\mathrm{Cl}_{\mathrm{VP}}-\mathrm{MCM}-41$ in liquid phase. A slight decrease in specific surface area at constant pore volume is a result of modifying only external surface of $\mathrm{Cl}_{\mathrm{VP}}-\mathrm{MCM}-41$.

Amino acids are the appropriate biologically important model adsorbates as they contain both basic and acidic functional groups in their structure, and have molecular dimensions comparable to pore sizes of MCM-41 silicas. Para-aminobenzoic acid was chosen from variety of amino acids for release kinetic studies due to its weak interaction both starting and modified silicas in phosphate buffer $(\mathrm{pH}=6.86)$ and hydrochloric acid $(\mathrm{pH}=1.00)$ solutions. This peculiarity of $p$-ABA is useful for clarification of surface nanovalves contribution to retention of aromatic amino acid in mesoporous space of carriers in aqueous media with different $\mathrm{pH}$.

Obviously, this is preferentially caused by weak interaction of loaded $p$-ABA with silanol and 3-chloropropyl groups lining pore walls of synthesized silicas. It has been found that $p-\mathrm{ABA}$ is not adsorbed on a surface of studied MCM-type silicas from aqueous media with $\mathrm{pH}=1.00$ and 6.86. Obtained results are in a good agreement with the data on para-aminobenzoic acid sorption on mesoporous silica with disordered structure [38].
Release of $p$-ABA from synthesized mesoporous silicas is mainly controlled by diffusion through cylindrical channels, and equilibrium is reached after several minutes. Kinetic curves of $p$-ABA desorption at $\mathrm{pH}=1.00$ from MCM-41, Cl-MCM-41, and Cl $\mathrm{Vl}_{\mathrm{VP}}-\mathrm{MCM}-41$ silicas are similar to its extrication profiles at $\mathrm{pH}=6.86$. The content of para-aminobenzoic acid filling the pore space of MCM-41, Cl-MCM-41, and Cl $\mathrm{VP}_{\mathrm{VP}} \mathrm{MCM}-41$ calculated from desorption data and thermal analysis of acid-loaded silica materials is represented in Table 2.

Liberation of $p$-ABA from mesoporous channels of MCM-41, Cl-MCM-41, and $\mathrm{Cl}_{\mathrm{VP}}-\mathrm{MCM}-41$ is characterized by immediate transition of biologically active compound into release medium (Fig. 3).

Selective immobilization of blocking groups onto external surface of Cl-MCM-41 and $\mathrm{Cl}_{\mathrm{VP}}-\mathrm{MCM}-41$ silica particles was realized to retain high loading capacity and provide controlled release of biologically active compound. The loading of EDA $\mathrm{VP}_{\mathrm{VP}} \mathrm{Cl}-\mathrm{MCM}-41$ and ADPA-Cl $\mathrm{VP}_{\mathrm{VP}}-\mathrm{MCM}-41$ with $p$-ABA determined by UV spectroscopy is equal to 1.23 and $0.83 \mathrm{mmol} / \mathrm{g}$ instead of 0.98 and $1.41 \mathrm{mmol} / \mathrm{g}$ for Cl-MCM-41 and $\mathrm{Cl}_{\mathrm{VP}}-\mathrm{MCM}-41$, respectively (Table 2). The reason for this probably is a change in specific surface area of Cl-MCM-41 and $\mathrm{Cl}_{\mathrm{VP}}-\mathrm{MCM}-41$ after chemical interaction with 1,2-EDA and 2-ADPA (Table 1). Chemical attachment of $\mathrm{N}$-(2-aminoethyl)-3-aminopropyl groups onto external surface of Cl-MCM-41 particles increases 
the amount of aromatic amino acid introduced into the pores of silica, and chemical immobilization of bulky N-[N'-(N'-phenyl)-2-aminophenyl]-3-aminopropyl groups from liquid phase reduces the quantity of $p$-ABA in silica mesopores volume (Table 2).

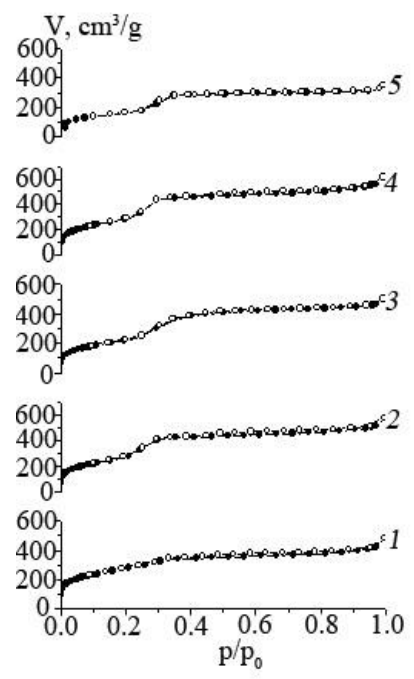

$a$

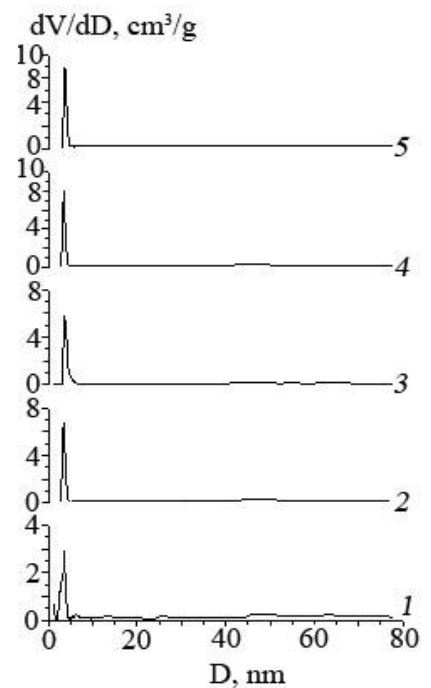

$b$

Fig. 2. Nitrogen ad-desorption isotherms (a) and pore size distributions (b) for MCM-41 (1), Cl-MCM-41 (2), $\mathrm{Cl}_{\mathrm{VP}}-\mathrm{MCM}-41$ (3), EDA $\mathrm{VP}_{\mathrm{VP}} \mathrm{Cl}-\mathrm{MCM}-41$ (4), and ADPA-Cl $\mathrm{VP}_{\mathrm{V}}-\mathrm{MCM}-41$ (5)

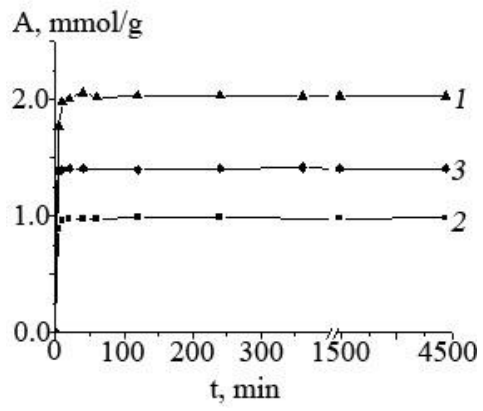

Fig. 3. Kinetic curves of $p-\mathrm{ABA}$ release at $\mathrm{pH}=6.86$ from $\mathrm{MCM}-41$ (1), $\mathrm{Cl}-\mathrm{MCM}-41$ (2), and $\mathrm{Cl}_{\mathrm{VP}}-\mathrm{MCM}-41$ (3)

Table 2. Content of $p$-ABA in pores of MCM-41 functional materials (by UV spectroscopy and thermal analysis data)

\begin{tabular}{|c|c|c|c|c|c|c|}
\hline \multirow[t]{3}{*}{ Silica } & \multicolumn{2}{|c|}{ Functional groups } & \multicolumn{4}{|c|}{ Content of loaded p-ABA } \\
\hline & \multirow{2}{*}{ chemical structure } & \multirow{2}{*}{ content, $\mathrm{mmol} / \mathrm{g}$} & \multicolumn{2}{|c|}{ UV spectroscopy } & \multicolumn{2}{|c|}{ Thermal analysis } \\
\hline & & & $\mathrm{mmol} / \mathrm{g}$ & $\mathrm{mg} / \mathrm{g}$ & $\mathrm{mmol} / \mathrm{g}$ & $\mathrm{mg} / \mathrm{g}$ \\
\hline MCM-41 & $\equiv \mathrm{SiOH}$ & - & 2.03 & 278 & 2.02 & 277 \\
\hline Cl-MCM-41 & $\begin{array}{c}\equiv \mathrm{SiOH} \\
-\left(\mathrm{CH}_{2}\right)_{3} \mathrm{Cl}\end{array}$ & $\begin{array}{l}- \\
-\end{array}$ & 0.98 & 134 & 0.92 & 126 \\
\hline $\mathrm{Cl}_{\mathrm{VP}}-\mathrm{MCM}-41$ & $\begin{array}{c}\equiv \mathrm{SiOH} \\
-\left(\mathrm{CH}_{2}\right)_{3} \mathrm{Cl}\end{array}$ & $\begin{array}{c}- \\
0.15\end{array}$ & 1.41 & 193 & 1.42 & 195 \\
\hline $\mathrm{EDA}_{\mathrm{VP}}-\mathrm{Cl}-\mathrm{MCM}-41$ & $\begin{array}{c}\equiv \mathrm{SiOH} \\
-\left(\mathrm{CH}_{2}\right)_{3} \mathrm{Cl} \\
-\left(\mathrm{CH}_{2}\right)_{3} \mathrm{NH}_{\left(\mathrm{C}_{2} \mathrm{H}_{4}\right) \mathrm{NH}_{2}}\end{array}$ & $\begin{array}{c}- \\
- \\
0.10\end{array}$ & 1.23 & 169 & 1.20 & 164 \\
\hline ADPA-Cl ${ }_{\mathrm{VP}}-\mathrm{MCM}-41$ & $\begin{array}{c}\equiv \mathrm{SiOH} \\
-\left(\mathrm{CH}_{2}\right)_{3} \mathrm{Cl} \\
-\left(\mathrm{CH}_{2}\right)_{3} \mathrm{NH}\left(\mathrm{C}_{6} \mathrm{H}_{4}\right) \mathrm{NH}\left(\mathrm{C}_{6} \mathrm{H}_{4}\right)\end{array}$ & $\begin{array}{c}- \\
- \\
0.11\end{array}$ & 0.83 & 114 & 0.89 & 122 \\
\hline
\end{tabular}


A comparative study of $p$ - $\mathrm{ABA}$ release profiles from $\mathrm{EDA}_{\mathrm{VP}}-\mathrm{Cl}-\mathrm{MCM}-41$ and $\mathrm{ADPA}-\mathrm{Cl}_{\mathrm{VP}}-\mathrm{MCM}-41$ was carried out in phosphate buffer and hydrochloric acid solutions. It was found that postsynthetic chemical modification of Cl-MCM-41 and $\mathrm{Cl}_{\mathrm{VP}}-\mathrm{MCM}-41$ with amine-containing groups of various structures did not provide full effect of $p$-ABA holding in silica mesopores. However, the amount of $p$-ABA which goes in a solution at $\mathrm{pH}=6.86$ (Fig. $4 a$ ) is less than that at $\mathrm{pH}=1.00$ (Fig. 4 b). It can be supposed that some anchored amino-containing groups are located closely enough to cooperate and prevent $p$-ABA release from mesopores at $\mathrm{pH}=6.86$. At $\mathrm{pH}=1.00$ repulsion of positively charged amino groups which are chemically attached to external surface of particles near by pore outlets of $\mathrm{EDA}_{\mathrm{VP}}-\mathrm{Cl}-\mathrm{MCM}-41$ and ADPA-Cl-MCM-41 silicas provides unhindered liberation of aromatic amino acid from mesoporous channels (Scheme 2). It should be noted that at high density of polyamines chemically grafted on external surface of silica particles its protonation leads to repulsion of brush-like packed functional moieties and closing of pore entrances [27].

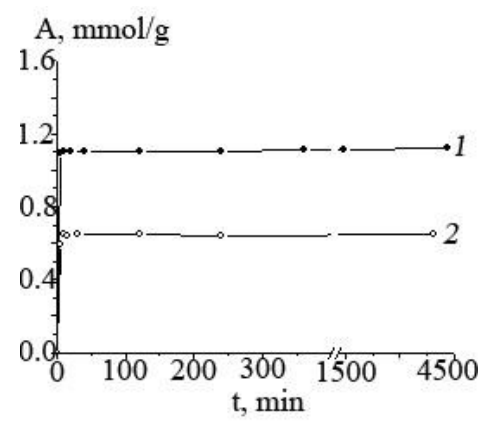

$a$

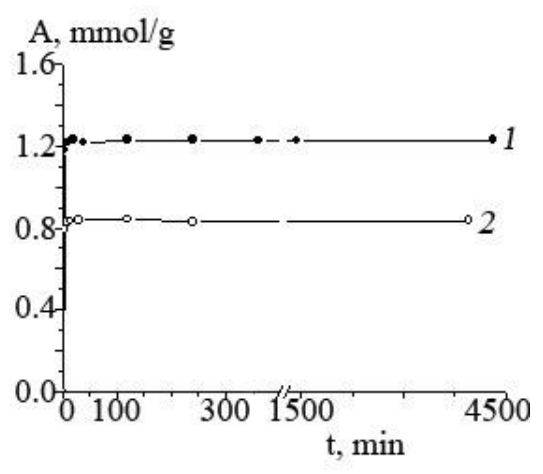

$b$

Fig. 4. Kinetic curves of $p$-ABA release from $\mathrm{EDA}_{\mathrm{VP}}-\mathrm{Cl}-\mathrm{MCM}-41$ (I) and ADPA-Cl $l_{\mathrm{VP}}-\mathrm{MCM}-41$ (2) at $\mathrm{pH}=6.86(a)$ and at $\mathrm{pH}=1.00(b)$
Additional measurements were carried out to confirm the role of $\mathrm{N}$-(2-aminoethyl)-3-aminopropyl and N-[N'-(N'-phenyl)-2-aminophenyl]-3-aminopropyl groups located on external surface of mesoporous silicas as nanovalves with $\mathrm{pH}$-controlled opening and blocking properties. Release kinetics was studied for $p$-ABA loaded $\mathrm{EDA}_{\mathrm{VP}}-\mathrm{Cl}-\mathrm{MCM}-41$ and ADPA-Cl $l_{\mathrm{VP}}-\mathrm{MCM}-41$ carriers preliminary rinsed with phosphate buffer solution $(\mathrm{pH}=6.86)$. As can be seen in Fig. 5, para-aminobenzoic acid retains in mesoporous channels of silica carriers equipped with $\mathrm{N}$-(2-aminoethyl)-3-aminopropyl or $\mathrm{N}$-[N'-(N'-phenyl)-2-aminophenyl]-3-aminopropyl groups at $\mathrm{pH}=6.86$ and liberates at $\mathrm{pH}=1.00$.

Delivery of $p$-ABA registered under neutral conditions $(\mathrm{pH}=6.86)$ is negligible that can be explained by blocking of pore entrances with surface amino-containing groups (Scheme 2, Fig. 5). On lowering $\mathrm{pH}$ value, the amount of liberated $p$-ABA increases rapidly (Fig. 5). Obviously, protonated amino groups grafted on external surface of silica particles are repulsed under these conditions, and pore entrances become accessible for release processes. Thus, triggering of $p$-ABA release can be induced by lowering $\mathrm{pH}$ value from 6.86 to 1.00 . Values of aromatic amino acid storage in blocked pores of rinsed $\mathrm{EDA}_{\mathrm{VP}}-\mathrm{Cl}-\mathrm{MCM}-41$ and ADPA-Cl $\mathrm{VP}_{\mathrm{VP}} \mathrm{MCM}-41$ silicas are in a good agreement with differences of $p$-ABA liberated from un-rinsed carriers in neutral and acidic media (Figs. 4, 5). The effects contributing the pore blockage are less pronounced in the case of $\mathrm{N}$-(2-aminoethyl)-3-aminopropyl groups. As it can be seen in Fig. 5, N-[N'-(N'phenyl)-2-aminophenyl]-3-aminopropyl groups retard the release of $p$-ABA from mesoporous channels more effectively than $\mathrm{N}$-(2-aminoethyl)-3-aminopropyl ones. As content of immobilized blocking groups in EDA $_{\mathrm{VP}}-\mathrm{Cl}-\mathrm{MCM}-41$ and ADPA-Cl $\mathrm{VP}_{\mathrm{PP}} \mathrm{MCM}-41$ silicas is commensurable, observed effect can be connected with distinctions in its geometrical dimensions. In general, $\mathrm{pH}$-controlled nanovalves which was constructed by chemical immobilization of N-(2-aminoethyl)-3-aminopropyl or N-[N'-(N'phenyl)-2-aminophenyl]-3-aminopropyl groups on outer surface of mesoporous MCM-41 silicas can be suitable for retention of biologically active amino acid and its delivery. 

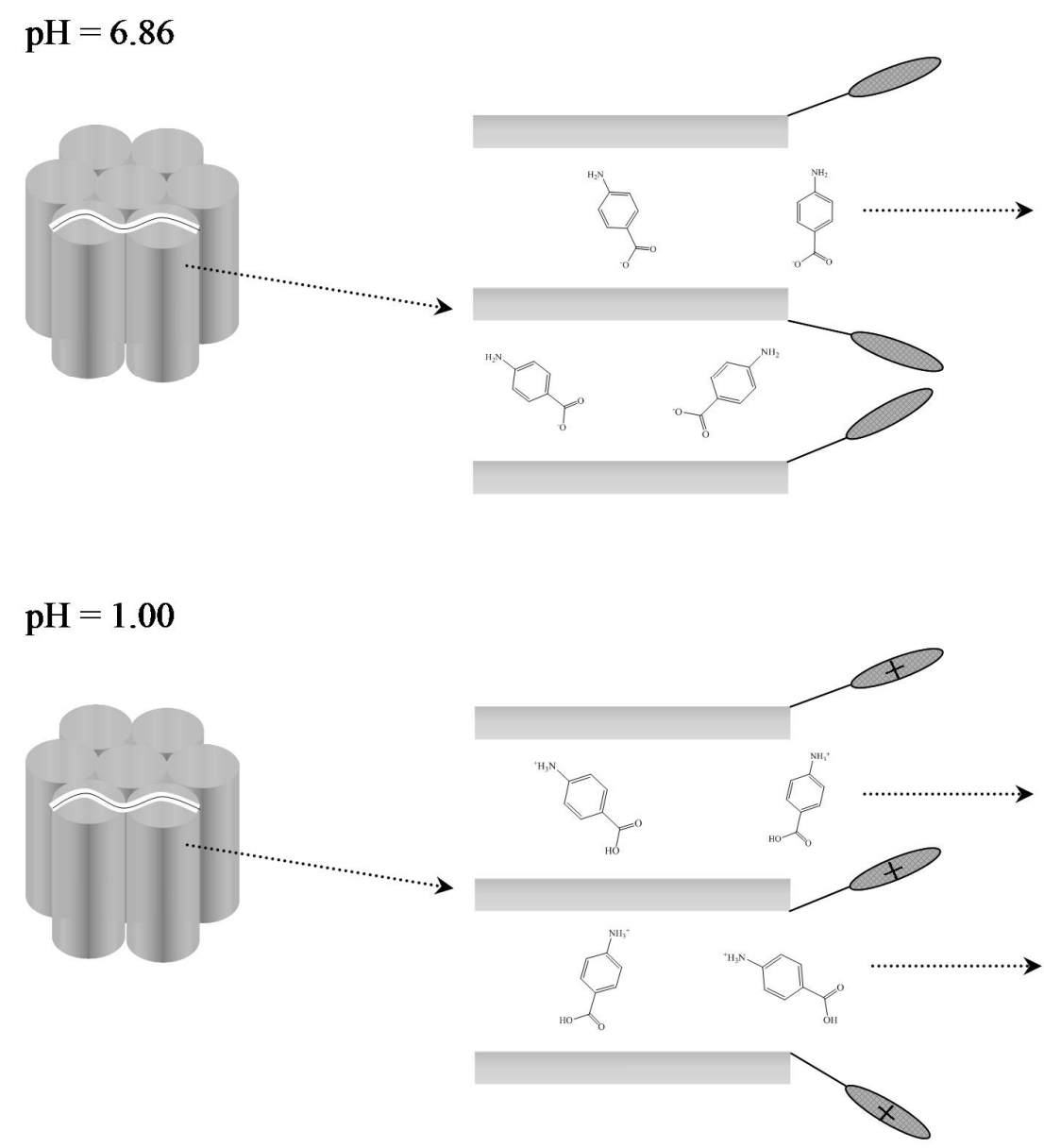

Scheme 2. Storage of $p$-ABA in blocked pore channels at $\mathrm{pH}=6.86$ and its liberation through opened pore entrences at $\mathrm{pH}=1.00$

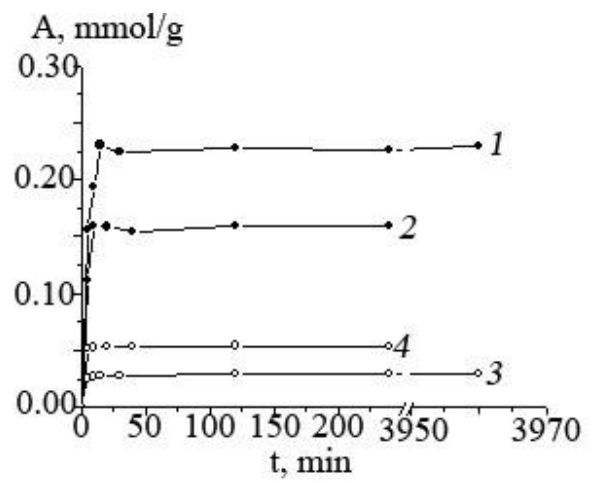

Fig. 5. Kinetic curves of $p$-ABA release from $\operatorname{ADPA}_{-\mathrm{Cl}} \mathrm{VP}-\mathrm{MCM}-41(1,3)$ and $\mathrm{EDA}_{\mathrm{VP}}-\mathrm{Cl}-\mathrm{MCM}-41(2,4)$ at $\mathrm{pH}=1.00$ and 6.86, respectively (after rinsing by buffer solution with $\mathrm{pH}=6.86$ )

\section{CONCLUSIONS}

The MCM-41-type materials with amino-containing functional groups located on external surface of silica particles were synthesized by combination of sol-gel method with postsynthetic chemical modification. Results of X-ray diffraction and low-temperature ad-desorption of nitrogen are an evidence that immobilization of $\mathrm{N}$-(2-aminoethyl)-3-aminopropyl or $\mathrm{N}$-[N'-(N'-phenyl)-2-aminophenyl]-3-aminopropyl groups on outer surface of silica particles leads to preservation of mesoporous structure of initial MCM-41 and Cl-MCM-41 silicas with cylindrical pores of uniform size. Despite different loading of 
mesoporous silicas, release kinetics has the same character. Obviously, content of $p$-ABA in mesoporous channels of silica carriers had no influence on drug release rate. It has been found that desorption of $p$-ABA from mesoporous channels of silica carriers occurs at the first contact with aqueous solution and has identical character in acidic and neutral media. Localization of blocking amino groups near by pore orifices provides preservation of high loading capacity of carriers and controlled liberation of biologically active compound at $\mathrm{pH}$ change. Blocking of pore openings arising from interactions between closely attached amino-containing functional groups of carrier at $\mathrm{pH}=6.86$ prevents para-aminobenzoic acid release, whereas at $\mathrm{pH}=1.00$ repulsion of protonated amino groups provides unhindered liberation of aromatic amino acid from its mesoporous channels.

\title{
Декорування входів у пори МСМ-41 аміновмісними групами для рН-контрольованого вивільнення пара-амінобензойної кислоти
}

\author{
Н.В. Роїк, Л.О. Бєлякова, М.О. Дзязько, О.І. Оранська \\ Інститут хімії поверхні ім. О.О. Чуйка Національної академії наук України \\ вул. Генерала Наумова, 17, Київ, 03164, Україна, roik_nadya@ukr.net
}

\begin{abstract}
Поєднанням золь-гель конденсаиї та пост-синтетичного хімічного модифікування одержано вибірково модифіковані кремнеземні матеріали з однорідними гексагонально впорядкованими чиліндричними мезопорами. Гексагональну структуру пор кремнеземних носіїв підтверджено даними рентгенівської дифракиії та низькотемпературної ад-десорбиії азоту. Вміст функиіональних груп, іммобілізованих на зовнішній поверхні частинок кремнезему, визначали з результатів хімічного аналізу продуктів реакиії. Здатність мезопористих кремнеземів, спрямовано модифікованих $N$-(2-аміноетил)-3-амінопропільними чи $N$-[N'-(N'-феніл)-2-амінофеніл]-3-амінопропільними групами, до вивільнення біологічно активних речовин вивчено на прикладі пара-амінобензойної кислоти. Встановлено, що десорбиію ароматичної амінокислоти з каналів мезопор кремнезему можна регулювати, використовуючи рН-чутливі функціональні групи, хімічно закріплені на зовнішній поверхні кремнезему.
\end{abstract}

Ключові слова: золь-гель синтез, парофазне модифікування, десорбиія, поверхневі властивості

\section{Декорирование входов в поры МСМ-41 аминосодержащими группами для рН-контролированного высвобождения пара-аминобензойной кислоты}

\author{
Н.В. Роик, Л.А. Белякова, М.А. Дзязько, Е.И. Оранская
}

Институт химии поверхности им. А.А. Чуйко Наџиональной академии наук Украинь ул. Генерала Наумова, 17, Киев, 03164, Украина, roik_nadya@ukr.net

Сочетанием золь-гель конденсачии и пост-синтетического химического модифицирования получены избирательно модифицированные кремнеземные материаль с однородными гексагонально упорядоченными иилиндрическими мезопорами. Гексагональная структура пор кремнеземных носителей подтверждена данными рентгеновской дифракиии и низкотемпературной ад-десорбции азота. Содержание функциональных групп, иммобилизованных на внешней поверхности частии кремнезема, рассчитывали из результатов химического анализа продуктов реакиии. Способность мезопористых кремнеземов, избирательно модифичированных $N$-(2-аминоэтил)-3-аминопропильными или N-[N'-(N'-фенил)-2-аминофенил]-3-аминопропильныли группами, к высвобождению биологически 
активных веществ изучена на примере пара-аминобензойной кислоты. Установлено, что десорбиию ароматической аминокислоты из каналов мезопор кремнезема можно регулировать, используя рН-чувствительные функциональные группы, хинически закрепленные на внешней поверхности кремнезема.

Ключевые слова: золь-гель синтез, парофазное модифицирование, десорбция, поверхностные свойства

\section{REFERENCES}

1. Kresge C.T., Leonowicz M.E., Roth W.J. et al. Ordered mesoporous molecular sieves synthesized by a liquid-crystal template mechanism, Nature, 359 (1992) 710.

2. Iskandar $F$. Ordered nanoporous particles, Encyclopedia of Nanoscience and Nanotechnology, Ed. by H.S. Nalwa, 8 (2004) 259.

3. Lin H.P., Cheng S., Mou C.-Y. Synthesis of thermally stable MCM-41 at ambient temperature, J. Chin. Chem. Soc., 43 (1996) 375.

4. Van Der Voort P., Mathieu M. et al. Synthesis of high-quality MCM-48 and MCM-41 by means of the GEMINI surfactant method, J. Phys. Chem. B., 102 (1998) 8847.

5. Jana S.K., Nishida R., Shindo K. et al. Pore size control of mesoporous molecular sieves using different organic auxiliary chemicals, Micropor. Mesopor. Mat., 68 (2004) 133.

6. Beck J.S., Vartuli J.C., Roth W.J et al. A new family of mesoporous molecular sieves prepared with liquid crystal templates, J. Am. Chem. Soc., 114 (1992) 10834.

7. Corma A., Kan Q., Navarro M.T. et al. Synthesis of MCM-41 with different pore diameters without addition of auxiliary organics, Chem. Mater., 9 (1997) 2123.

8. Gao T., Wen C., Long C. et al. Effects of assistant agent on mesoporous structure of silica MCM-41 molecular sieves, J. Wuhan Univ. Tech., 20 (2005) 60.

9. Нио Q., Margolese D.I., Stucky G.D. Surfactant control of phases in the synthesis of mesoporous silica-based materials, Chem. Mater., 8 (1996) 1147.

10. Sayari A., Liu P. Characterization of large-pore MCM-41 molecular sieves obtained via hydrothermal restructuring, Chem. Mater., 9 (1997) 2499.

11. Sutra P., Fajula F., Brunel D. et al. ${ }^{29} \mathrm{Si}$ and ${ }^{13} \mathrm{C}$ MAS-NMR characterization of surface modification of micelle-templated silicas during the grafting of organic moieties and end-capping, Coll. Surf. A., 158 (1999) 21.

12. Yang H., Zhang G., Hong X., Zhu Y. Silylation of mesoporous silica MCM-41 with the mixture of $\mathrm{Cl}\left(\mathrm{CH}_{2}\right)_{3} \mathrm{SiCl}_{3}$ and $\mathrm{CH}_{3} \mathrm{SiCl}_{3}$ : combination of adjustable grafting density and improved hydrothermal stability, Microp. Mesopor. Mater., 68 (2004) 119.

13. Bae J.A., Song K.-C., Jeon J.-K. et al. Effect of pore structure of amine-functionalized mesoporous silica-supported rhodium catalysts on 1-octene hydroformylation, Micropor. Mesopor. Mater., 123 (2009) 289.

14. Lesaint C., Lebeau B., Marichal C., Patarin J. Synthesis of mesoporous silica materials functionalized with $n$-propyl groups. Micropor. Mesopor. Mater. 83 (2005) 76.

15. Yoshitake H., $\quad$ Koiso E., $\quad$ Horie H., Yoshimura $\mathrm{H}$. Polyamine-functionalized mesoporous silicas: Preparation, structural analysis and oxyanion adsorption, Micropor. Mesop. Mater., 85 (2005) 183.

16. Daehler A., Boskovic S., Gee M.L. et al. Postsynthesis vapor-phase functionalization of MCM-48 with hexamethyldisilazane and 3-aminopropyldimethylethoxylsilane for bioseparation applications, J. Phys. Chem. B., 109 (2005) 16263.

17. Slowing I.I., Vivero-Escoto J.L., $\quad W u$ C.-W., Lin S. $Y$. Mesoporous silica nanoparticles as controlled release drug delivery and gene transfection carriers, Adv. Drug Delivery Rev., 60 (2008) 1278.

18. Patel K., Angelos S., DichtelW.R. et al. Enzyme-responsive snap-top covered silica nanocontainers, J. Am. Chem. Soc., 130 (2008) 2382.

19. Zhao Y., Trewyn B.G., Slowing I.I., Lin V.S.-Y. Mesoporous silica nanoparticle-based double brug delivery system for glucose-responsive controlled release of insulin and cyclic AMP, J. Am. Chem. Soc., 131 (2009) 8398-8400. 
20. Nguyen T.D., Tseng H.-R., Celestre P.C. et al. A reversible molecular valve, PNAS, 102 (2005) 10029.

21. Nguyen T.D., Leung K.C.-F., Liong M. et al. Construction of a $\mathrm{pH}$-driven supramolecular nanovalve, Org. Lett., 8 (2006) 3363.

22. Angelos S., Yang Y.-W., Patel K. et al. $\mathrm{pH}$-responsive supramolecular nanovalves based on cucurbit[6]uril pseudorotaxanes, Angew. Chem. Int. Ed., 47 (2008) 2222.

23. Park C., Oh K., Lee S.C., Kim C. Controlled release of guest molecules from mesoporous silica particles based on a pH-responsive polypseudorotaxane motif, Angew. Chem. Int. Ed., 46 (2007) 1455.

24. Guo W., Wang J., Lee S.J. et al. A general pH-responsive supramolecular nanovalve based on mesoporous organosilica hollow nanospheres, Chem. Eur. J., 16 (2010) 8641.

25. Meng H., Xue M., Xia T. et al. Autonomous in vitro anticancer drug release from mesoporous silica nanoparticles by $\mathrm{pH}$-sensitive nanovalves, J. Am. Chem. Soc., 132 (2010) 12690.

26. Hernandez R., Tseng H.-R., Wong J.W. et al. An operational supramolecular nanovalve, J. Am. Chem. Soc., 126 (2004) 3370.

27. Casasus R., Marcos M.D., Martinez-Manez R. et al. Toward the development of ionically controlled nanoscopic molecular gates, J. Am. Chem. Soc., 126 (2004) 8612.

28. Choi H.S., Huh K.M., Ooya T., Yui N. pH- and thermosensitive supramolecular assembling system: rapidly responsive properties of $\alpha$-cyclodextrin-conjugated poly(E-lysine), J. Am. Chem. Soc., 125 (2003) 6350.

29. Park C., Lee K., Kim C. Photoresponsive cyclodextrin-covered nanocontainers and their sol-gel transition induced by molecular recognition, Angew. Chem., Int. Ed., 48 (2009) 1275.

30. Mal N.K., Fujiwara M., Tanaka $Y$. Photocontrolled reversible release of guest molecules from coumarin-modified mesoporous silica, Nature, 421 (2003) 350.

31. Bragg W.L. The diffraction of short electromagnetic waves by a crystal, Proceedings of the Cambridge Philosophical Society, 17 (1913) 43.

32. Fenelonov V.B., Romannikov V.N., Derevyankin A.Yu. Mesopore size and surface area calculations for hexagonal mesophases (types MCM-41, FSM-16, etc.) using lowangle XRD and adsorption data, Micropor. Mesopor. Mater., 28 (1999) 57.

33. Kruk M., Jaroniec M., Sayari A. Adsorption study of surface and structural properties of MCM-41 materials of different pore sizes, J. Phys. Chem. B., 101 (1997) 583.

34. Pohloudek-Fabini R., Beyrich Th. Organische Analyse, Akademische Verlagsgesellschart Geest und Portig K.-G., Leipzig, 1975, 608 p.

35. Williams W.J. Handbook of anion determination, Butterworths, London, 1979, $630 \mathrm{p}$.

36. Helfferich F.G. Ion exchange, Dover Publications Inc., New York, 1995, 640 p.

37. Roik N.V., Belyakova L.A. Sol-gel synthesis of MCM-41 silicas and selective vapor-phase modification of their surface, J. Solid State Chem., 207 (2013) 194.

38. Roik N.V., Belyakova L.A. Interaction of supramolecular centers of silica surface with aromatic amino acids, J. Coll. Interf. Sci., 362 (2011) 172.

Поступила 08.07.2014, принята 17.09.2014 